\title{
The Communication of a Religiousness Ritual of Toraja Ethnic South Sulawesi Indonesia through Ma'Badong Inheritance Media
}

\author{
Muslimin M. ${ }^{1}$ \\ ${ }^{1}$ Faculty of Social and Political Science University of Muhammadiyah Malang Indonesia, Indonesia \\ Correspondence: Muslimin M., Faculty of Social and Political Science University of Muhammadiyah Malang \\ Indonesia, Indonesia. E-mail: machmudmus@gmail.com
}

\author{
Received: April 21, 2015 Accepted: May 11, 2015 Online Published: August 18, 2015 \\ doi:10.5539/ass.v11n24p129 URL: http://dx.doi.org/10.5539/ass.v11n24p129
}

\begin{abstract}
Ma'badong inheritance media, beside as Toraja's media in expresing their grief when there was a family member, kinfolk, neighbour, or a society member had passed away, but also had a function as an perpetuation of Toraja's society culture's value, because in fact Ma'badong inheritance media was not only utilized by the Toraja's society members as the Toraja's germinal, but also was utilized by Toraja's people who lived out of Toraja's region. Ma'badong became very popular because it was a last offices completeness as the main precept for Aluk Todolok's followers (native religion) within Toraja's society. It meant, even Toraja's society lived out of Toraja's area, however if there was its society member passed away, Ma'badong would still done as a togetherness form and a dedication expression from the living until died. Thus, the function of Ma'badong which was done by Toraja's people who lived out of the area would be fold, thus beside as a last office completeness, also as a culture unifier and perpetuation by Toraja's people.
\end{abstract}

Keywords: religious ritual communication, Toraja ethnic, Ma'badong

\section{Introduction}

Ma'badong (Note 1) was a dance which was followed by a grief song. The dance and song contained of grief rhyme where was done in the Toraja's last offices. Ma'badong dancing was done in group by making a big circle that was followed by a regular movement. The purpose of Ma'badong dancing was to give an admiration for them who passed away by revealing the goodness that was done when the dead was still alive. Pa'badong wore uniform, commonly in black and wore black sarong or Toraja's costume. In Ma'badong, all parts of Pa'badong members' body was also moved, such as moved the head to the front and back, the shoulder going forward-backward, both of the arm was swung together to the front and back, hand in hand, when sometimes the foot was kicked to the front and back by substitution. Based on that highlight, it could be firmed that the form of communication in the message delivering was compounding between verbal and nonverbal communication.

Ma'badong was done in the last offices moment on a wide field, it was in the middle of Lantang (Note 2) Pa'badong wore uniform, commonly black and wore a black sarong or Toraja's costume. The number of the dancers could reach until hundreds of people, because Ma'badong was opened for people who intended to extend their condolences, became a guest of the last offices who intended to participate Ma'badong would be allowed to participate by wearing free costume.

\section{Ma'badong Procession}

A large circle was made when Ma'badong for a moment narrowed by moving forward the Pa'badong's members, then again moving backward, escalating the circle and rotate each other so that they could turns their position, however they would not move among the other Pa'badong who were in the right and left side. The song rhyme which followed the Ma'badong dancing was the Pa'badong song, without the music offbeat. The played song was in Toraja language, in the form of rhyme (Kadong Badong) contained of the life history or life journey of the person who passed away, started from the newborn until died. Beside the life history rhyme, Ma'badong also contained with pray, in order that the death spirit could be accepted, saved and given the best place in the grave.

Commonly the Ma'badong activity was going on three days and three nights, and during the moment of the dead person's family continuously accepting guests from whether close family, close friends, or society members who intended to extend the condolences. Indeed for Toraja's people, if there was their family member who passed 
away, the corpse would not directly be graved but commonly they waited for the family connections that would come from the far resident. Therefore, commonly the Toraja's last offices was going on three days, however sometimes there were families who held the last offices that was going on five and seven days, or in the other words Ma'badong was going on in the variety of time appropriated with the Pa'badong pretension and the family's (Note 3) agreement.

In the past, the last offices performance in Tana Toraja was done only by raja and noble's generations, and the high social status families that were people who had a lot of wealth. In other words, Ma'badong activity was done only by the rich society as the coordinator, however Pa'badong itself was a family and public society in which voluntarily intended to pray to the dead person. Nowadays, Ma'badong could be done by all classes. Commonly Pa'badong was the native Toraja who lived in Toraja for long time and was strongly knew their culture, so that they would not face any difficulty in singing the Ma'badong song rhyme. Besides, because of the last offices was still commonly held, it caused the Toraja's society was not insufficient and could do Ma'badong activities well and fluently.

Related to Ma'badong activity, the writer even met some Toraja's socialite, for example was Simon Petrus, 63 years old, who worked as Culture Science lecturer in the University of Paulus Christian Indonesia, Makassar. In South Sulawesi, he knew as the Toraja's Socialite, Toraja's Culture Observer and Ma'badong performer of inheritance media show. Simon, his close nickname, said that Toraja's society was also knew internationally, beside because of the nature beauty it was also caused by their culture seemed to be unique, original, and natural, as the result that the inheritance media show was still used, moreover it could be considered to be parts of Toraja's society. For example, there were some dances called as Ma'badong, Passailong, Pa'dondi, Sengo', $P a^{\prime}$ katiak, Ma'gellu and Pa'barrung, all of them were still exist and developed in the society because it was supported by the supporter society (their communal society). It could be exist because the society who had an inheritance media was experiencing the benefit particularly in the togetherness spirit where it can be formed as a togetherness, mutual cooperation, and good relationship. And among the Toraja's inheritance media which was still exist Ma'badong was an activity that was held almost every time.

In the activity implementation of Ma'badong it might not be held individually but in togetherness. Beside Ma'badong, in the Toraja's last offices it was commonly begun with the recognition of the condolences family, a stripe water buffalo (bonga), water buffalo which will be slaughtered. There was an activity called as "mapasilaga tedong" (fought water buffalo, then would be slaughtered as the spirit's deliver to the heaven), the chest procession to the available place, coin strewing in order to be carried by the ceremony guests, and the slaughtered animal burning that would be given to the families, guests, and the societies, including performing other rituals.

As was explained that nowadays Ma'badong activity that was done by Toraja's society, had a role as a completeness that might not be missed in the Toraja's society last offices procession, it meant that Ma'badong was only done in the last offices, indeed there was almost all of Toraja's society could participate in holding Ma'badong ritual. In the Ma'badong there was a leader who was called as Indo' Badong. Before Ma'badong was begun, a ceremony preparation was commonly done, where all the condolences family members decided whoever would be Pa'badong for the last offices whether from the family members, family connections, colleagues, neighbors, or others. When the last offices were going on, the selected people went to the given place. The Pa'badong members stood and waited for the other participants to occupy their each position and status then Indo' Badong gave a sign to start their dance.

In the beginning of Ma'badong, the Pa'badong members sang four Badong songs continuously appropriated with the function, that were Badong Pakilala (advice), Badong Umbating (mourning), Badong Ma'palao (procession), and Badong Pasakke (prosperity or blessing). After that, continued by the Pa'badong members who prepared the pray and life history songs. When the time of Ma'badong activity was over, while the Badong rhyme, pray, and life history songs had not finished yet, the Pa'badong members would stop for a moment simultaneously and they went back to Lantang to take a rest, then they would continue the Ma'badong ritual in order to finish the uncompleted parts. This way was going on, so that the dance and Pa'badong song finished and the last offices had seemed to be done.

\section{Ma'badong as the Religion Ceremony Completeness}

In the Toraja's society, they believed the native religion that was called Aluk Todolok (Note 4). This native religion was believed as the guaranties element of the whole nature everlasting included the society. Alok Todolok was believed to be able to assure the harmony, balance, the concord or reconciliation. Therefore, if there was a disaster, war, disease, business failure, that could organized as plant disease attack, fire, inharmonic among 
society, society trouble and the like, then it could be determined that all the incidents were caused by an infraction of Aluk (religion). Therefore, for Toraja's society in that effort to avoid any infraction of Aluk, it was needed to hold a religion ritual, where the inheritance media show was done as the completeness of Toraja's native religion ceremony. Thus, the characteristic of inheritance media in the Toraja's native religion was the functional it meant that it could be used only when they kept Rambu Solok (Note 5) ceremony (last offices) that were series of the Toraja's native religion implementation that was called as Aluk Todolok.

In the Tana Toraja custom, the society believed that after death there would be a 'world. That 'world' was an eternity place where the forefathers were got on together. And it was used as a rest place. Toraja's society called it as Puya (Note 6), where located in the south of Tana Toraja. In this Puya, the dead spirit would transform, be a roam spirit (Bombo), an as high as God spirit (To Mebali Puang), or guardian spirit (Deata). Toraja's society believed that the transformation form depended on the perfection of the Rambu Solo ceremony procession. Therefore, Rambu Solo was also as perfecting last offices. In addition, Rambo Solo had become an obligation for the left family, because only by Rambu Solo, the dead spirit could reach perfection in Puya. Therefore the left family would make a maximum effort in order to hold Rambu Solo ceremony. But then, it was needed not little cost by a family in holding Rambu Solo. Therefore, Toraja's funeral ceremony mostly held within months to years after the death.

Ma'badong was an inheritance media show which had a sacred and functional characteristic, meant that it could not be done any time, but it was only done at the time Toraja's funeral ceremony (as explained in the previous chapter that in the past there was only noble who was able to hold Ma'badong activity, but now even they were not a noble, if they had ability to hold Rambu Solok ceremony which consisted of Ma'badong activity). If the Ma'badong activity was done toward society whom not a noble, actually it could be explained that Ma'badong as a show and medium to entertain them whom grieving, or as a symbol that the dead one was Toraja's society.

There were strata or caste in Toraja's society that influenced the society growth and Toraja's society culture. Moreover, strata were not only applied to humans, but also to the water buffaloes. There was water buffaloes with the same weight but had different price. The price of water buffaloes with the high strata was probably to reach Rp. 100.000.000, while the water buffalo with the low strata just Rp. 5000.000. Water buffalo with the highest strata was called TedongBonga (Note 7). In the funeral ceremony which was called as Rambu Solok, there must provided Tedong Bonga, the number was not limited but at least there was one. However, in viewing the high and low caste of person who passed away, it might not only be seen from the number of slaughtered Tedong Bonga, because even there was a noble generation but if the financial ability was limited then it would be enough by one or two water buffaloes, on the contrary even the dead person was not from high enough caste but had a good financial ability, it was permitted to slaughter illimitable Tedong Bonga as the capability.

\section{Reasons in Holding a Great Cost Funeral Ceremony}

Tana Toraja's society believed that Rambu Solo would perfect someone's death. Therefore, they had a hunch that someone who passed away and was not holding Rambu Solo ceremony yet, the dead person was believed not passed away yet. The dead person would be treated as a sick person or in a weak condition. That person who was believed did not pass away yet, also would be treated as a life human by the family members. Like the person was rested on the bed if went to sleep, offered food and drink, and asked to tell a story and cracked jokes as usual, as when that person was still alive. This treatment was done to the dead person by all family members, even the surrounding neighbors.

Aluk Todolo belief had a precept about a relationship of human (alive) with a dead person, meant if there was a new death and the funeral was not holding a ceremony yet, so the dead person was believed only as a resting one or in sick condition that was commonly called as Tomakula'. As long as in this condition the relationship among the life humans was in the usual condition, where Tomakula' was needed as an alive human because in the daily condition provided by food and drink that was laid on the special plate and cup for Tomakula'.

Simon as the informant when the interview was done further explained that the Toraja's society's reason in holding custom ceremony of a death perfecting, aimed to respect and accompany the dead spirit to the spirit world that was back to eternity with the Toraja's forefathers in the eternity rest place. In order to face and prepare the Toraja's society last offices, it was commonly begun by activities related to the preparation of that custom ceremony. Introducing activities were done before holding the ceremony, they were family meeting, ceremony cabin making, ceremony tools providing, and ceremony offering providing. After all the beginning ceremony, then there would be held the real ceremony as the arrangement of Aluk Todolo belief. A Toraja's funeral ceremony had a wide meaning and it was needed a wealth sacrificial in the high number. Therefore, it caused a funeral ceremony was able to be held after weeks, months, even years since the death. The last offices 
postponement aimed to let the left family collected enough money in order to cover the funeral cost. Toraja's tribe believed that a death was not only something which happened suddenly, but also was a step of processes to reach Puya. In the time of waiting, the corpse was wrapped with cloths then saved under Tongkonan. A dead spirit was believed still alive in that village until the funeral ceremony had done, then the spirit would have a journey to Puya. A great and expensive (Note 8) sacrifice within Toraja's funeral ceremony was based on four aspects they were:

The first was religious reason. Toraja's people believed that the sacrifice of the slaughtered water buffalo could save the dead person. The sins that had done in the world could be cleared by slaughtering as many as possible water buffaloes, where the meat was ate by many people, including they who was ever maltreated, angered, or cruelled when the dead person was alive. When eating the water buffalo's meat so their sins would vanished. Toraja's society followed a hereditary belief that until now believed that everything had a soul in this world, even human, would had everlasting life even the body had dead. Moreover, Toraja's society faced the dead person by keep giving eat, drink, even there were something given when providing meal. It indicated that they believed as if the dead person was still alive and needed to be fulfilled all the need of eating and drinking even they had gone. Therefore, Toraja's people considered that the corpse of the dead person had to be venerated.

Grief was a condition where people who grieved would feel an affliction caused by a losing incident of the valuable person and would tend to follow the believable system in facing the last offices incident. Thus, they made hard effort in order to hold ceremony or praying rituals in order to calm themselves down, entertain, and become a spiritual advice related to the loss feeling was they experienced.

The second was loving reason to the parents or family connection. For Toraja's people, a death concept was meant that there was no greater losing than the death of the beloved persons such as, parents, siblings, and the spouse. Therefore, a death was a permanent farewell symbol with the beloved persons. This death caused individual experienced pain whether in social, emotional, or psychological because of the closeness with the dead person, as the result when losing the beloved person, it had to be faced by sacrificing the wealth in order to gratify the beloved one even the one had gone. Therefore, how poor the Toraja's people were, if their parents or family members had passed away, they would had a hard struggle in order to provide or sacrifice some the best water buffaloes for them. It was a love form to the family members or parents. Thus, a child wished by slaughtering water buffaloes, his dead parents would get the best rest place in the grave and released from any difficulties.

The third was prestige reason. In the Toraja's belief more power more water buffaloes had to slaughter. The slaughtered water buffalo was placed in line on the large field so that it could be seen by people. Placing the water buffaloes in line aimed to wait the owner who was still in the "rest time" (the dead person). Toraja's tribe believed that a spirit needed water buffalo in order to do a journey and more water buffaloes were slaughtered it would be quicker for the dead person to reach heaven. Slaughtering tens of water buffaloes and hundreds of pigs was the funeral ceremony climax which also indicated a stratification sign. More water buffaloes were slaughtered indicating that the dead person was devoting to the parents or the dead family. This was a self esteem symbol which was had by Toraja's people. Therefore, there were sons of Toraja's tribe felt became success if they were able to slaughter as many as possible water buffaloes in the Rambu Solok ceremony, because it was a success measurement that was also a prestige measurement.

And the forth was economic reason. Toraja's last offices were held appropriated with the family economical readiness because it was needed high cost. For the noble who had financial ability, commonly they would directly held the ceremony at the time their family member's died, but for the usual society, they would waited until they had enough cost. In order to wait that cost sufficiency, the corpse was commonly lied down in the Tongkonan and was prepared the need of eat and drink such a life person. In preparing the last offices, each of the family members made a serious effort to provide or render all their wealth for the need of last offices. It was done because it would determine the acquisition of the inheritance distribution from the left wealth. For Toraja's society, each of the inheritor who gave the most participation or the most sacrificing of water buffaloes at the moment of Rambu Solok, so the persons involved automatically had a right to get more inheritance wealth than the inheritor who sacrificed a little water buffaloes (was an unwritten determinate or simultaneous consensus in the Toraja's society). In order to determine who the contributor and how much had to contribute, commonly it was done a meeting among families, where could engage the inheritor and was not inheritor such as the elders and the government elements. That family meeting aimed to make a decision and had to be agreed by all parts particularly the inheritor or generation. Specifically, decisions had to be chosen in the family meeting such as talking about the determination or agreement of the funeral ceremony level. That ceremony level was adapted by the ability in providing slaughtered animal and the social strata of the dead person. It was also talked about the 
determiner of the slaughtered animal number based on the animals that were prepared by the inherited even not an inherited. It was also agreed about the ceremony holding, such as it was centralized in the dead person's house, field, or was determined in Tongkonan (Note 9). This matter needed to be determined in the family meeting or talking about the preparation of the ceremony cabin. All the needed things were completely prepared by the main family, but it was not impossible to receive any help from the other parts, because sometimes there were things that were also prepared by the other parts outside of the inherited. Therefore, principles in preparing all the needed things in the ceremony were done communally and were helped by the environs society members.

Related to the wish about Ma'badong inheritance media show, Simon described that there was an anxiety, particularly when seeing the technology of information and communication development at this time, in addition the youth attitude that was influenced by the modern media development. They seemed more interested toward modern things and irresponsive toward their forefathers' custom, which was reputed as an old-fashioned thing. Even though they were believed that as the custom formula stated that, "As long as there was an endorser of a custom then that custom would always exist". Therefore, it was needed a management and resuscitation especially to the youth in order to consider the Toraja custom. Therefore, for Simon, he was not hesitant and worry about the continuance of Ma'badong inheritance media because the Ma'badong activity was an inheritance so that it was believed that as long as Toraja's society was still exists, the custom would be exists, too. In addition, there was also an attention from the government, even it was limited in the facility providing. It was realized that the most prominent thing was not only about the facility, but also the government staffs who should be able to create a suitable climate with the regional custom development. Because a custom product which was presented regionally had a role as a local policy which was inherited for hereditary and the benefit was felt by the native society of the custom.

Because Ma'badong was a custom product where was orally inherited from a generation to the next generation, so the government parts were not allowed to interfere in the format, especially if the reason was only for tourism then it was packed by giving priority to the performance aspect and forgetting the guidance aspect. If it happened, it would be a danger and threaten as exist of the custom product.

Toraja's figure who also gave an explanation about the Ma'badong inheritance media show was Luther Tito, 54 years, who worked daily as a teacher in the Public Vocational High School 80 Parepare. He was a Toraja's society member and the elder of Toraja's society organization in Parepare, also as the player of Ma'badong inheritance media show. When describing about Ma'badong inheritance media show which was knew by Toraja's society, Luther said that Toraja's society had a similarity with other societies in South Sulawesi, was a custom society, it meant that the society's behavior was based on the religion precept and custom guidance which was being a habit in their life way, especially for Toraja's people and commonly for South Sulawesi native.

Therefore, in the Toraja's daily life they followed the custom which full of custom ceremonies, where one of the completeness was the inheritance media show. Started from wedding ceremony, baby birth welcome, riding oscillation, ground treading, house building, house moving until passed away, the ceremony would still be done. Therefore, it could be said that in Toraja's society and South Sulawesi totality, an inheritance media show was not a separated part, because it was the completeness in the ceremony.

Until now, Toraja's society still knew about the variance of inheritance media, but there were things that difficult to describe that caused by the death of the player, also the instrumentation was difficult to find. The most popular in Toraja's society was Ma'badong show, which was done in the form of blending among movement and orally rhyme which was guided by someone who was called Indo Badong (meant as Badong guidance).

According to Luther, Ma'badong was very popular because it was last offices completeness in the Toraja's society. It meant that even the Toraja's society lived outside of Toraja's region, but if there was any society member passed away, Ma'badong would still be done as the form of togetherness and as a dedication expression from the life to the dead. Therefore, there were fold function of Ma'badong which was done by Toraja's people who lived outside of the region, beside as the completeness in the last offices, also as a developing and perpetuation medium of Toraja custom.

Related to the struggle in perpetuating Ma'badong inheritance media show, Luther described that the government parts, especially Tanah Toraja regional development, giving high attention to the folk art perpetuation efforts of Toraja's society, because almost all of the regents were the native of Toraja who was mostly understand with the Toraja's custom and tradition. Luther explanation, was also supported by the law which said that regional custom should be exist and develop. Therefore, based on the moral and social responsibility, for Toraja's people, even they lived outside of Toraja regional, they would always introduce 
Toraja custom and tradition to the Toraja's youth generation, so that the custom and tradition as hereditary cared and exist because of the inheritors.

Undeniable fact, that Ma'badong activity was still exist until now in Toraja, it gave an evidence that the youth generation seemed enthusiastic to eternity the Toraja's custom and tradition, moreover they lived in Toraja. It was an obligation for them to learn, understand, and eternity the Ma'badong activity as the part of last offices which was very respected by Toraja's people. The anxious thing was supposed to Toraja's people who lived outside of Toraja region, because they were certainly influenced by the other factors such as foreign custom or modern mass media.

\section{The Heritage Media in the Perspective of Cross Culture Communication}

The perspective of cross culture communication in the context of media can be explained that the cross culture communication approach is meant by the more positive review toward the purpose of the media itself in order to comprehend the significance and role that are carried by the culture of certain society's life such as teenagers, workers, ethnical groups, or other groups in a society. The cross culture communication approach is also aimed to explain about the roles of culture in integrating and making dicipline a society that is potentially to deviate the society's norms and values, with the result that this approach is trying to comprehend the society's message by comprehending the social experience of small groups in the society as thoroughly, critically, and directionally, in order to give an explanation that is involving of the choice pattern or reaction toward the media (McQuail,1989:66-67).

As a cultural phenomona, the religious message that is delivered by the heritage media, as an example is Ma'badong, is cannot be separated by the cultural context generally. Moreover, if the belief that is expanded by a certain society, including Toraja, is agreed as the part of culture, therefore the process since the belief is received until how the society carry out their belief, at least it cannot be separated from the using of symbols that is believed contain of the holy and sacred values. Therefore, the cross culture communication perspective in the study of media consider the communication phenomena as the people connectiong process in the context of society. In this case, the components of that process have a role as a producer and user where each part defines the existing of communication by their interest as the pragmatic function of their culture. The existing of media is reviewed as contextually by the reality of the society as the expanse. Basicly, the reality of society can be distinguished as the empirical reality that come from the social interaction and physical reality that come from the human thought. This will carry out information that is chategorized as factual and fictional, with the objective and subjective function as the interaction process.

According to that case, in one of his article, Joachim Wach (1960) states that all of the religions or believes is indicationed by three universal expressions such as theoritical, sociological, and practical. Those three things are explained by Wach as follow:

"Theoretically, religion always implicate the matters that are believed by the believers, that is verbally can be expressed by the believing system in the form of myth or religion theory. Myth is a sequence of a narration that is including the society vission from the environment. Myth visibly cannot be believed as a right thing, but in all of the society's cases, myth is psychologically right. Meanwhile, religion theory is the next stage from the developmenting theory in the religion that rationalizes an inconsistency of myth, also a practice to explore some phenomenas by make them intellectually logic. Therefore, religion theory can be said as a more concrete way than myth. Religion theory consists of doctrine, dogma, theology, and religion theory. Socially, religion always related to the social aspect, it means that the religion review is cannot be separated from the social context. Religion always involving a social relation system and the individual role in a society's life. Whereas, based on the sociological form of religion, the existance can be seen in the church thypology, sect thypology, even cult thypology (worship a human), those things are the form of the most general religion sociology in the traditional or modern society. Practically, relegion is always related to holy things. Therefore, prayer which is done by an individual or in group, in the form of worship, meditation, haji, holy war, and sacrificing ritual are the kind of religion practices that are related to holiness."

In the religion message, the communication form is called by ritual communication (Mulyana, 2007:27) that is a kind of communication that is done collectively in the form of ceremonies. The ritual communication practice through the funeral ceremony of Ma'badong in the Toraja society in South Sulawesi is always performed in group, especially if there is a society's part died. In that ceremony, the people say some words or symbolizing behaviors, and other rituals such as praying, saying magic word, burning incense, sounding gong, offering flower or food, and so on. People who mixed up with that ritual, clarify their commitment toward the tradition of their family, community, communal, nation, ideology, and religion. 
The heritage media which has a characteristic, nature, posotion, function, and carry an impact, directionally will has a potential and strength. Therefore, in packing the message that will be delivered by the players in the heritage media performance as the communicator have to consider the audiences' demand and necessity as the message receiver. Therefore, it means that the player as communicator have comprehended the demand of current development that leads to the form of performance that is appropriate with the nature and desire of the society itself.

The condition of society and culture of South Sulawesi in the form of custom, tradition, and the change-over, including the change of heritage media performance, in the scope of social or cultural change, resulting a comprehension in this study, that the change will always keep the society's identity. Identity is an important thing in the cross culture communication perspective because it intimates the character of society and culture that is able to help in understanding the function and meaning of the society's activities.

Ma'badong as a kind of heritage media in Toraja, is called as "Cultural Commodities". It means that the performance material is a commodities which is produced then can be sold (in the form of CD, DVD, Vidoe tape). Therefore, professionally it can be said that the heritage media is an activity that have to be valued, because in the production process it involves and needs some people's skill so that is created a collaboration process. People who are involved in Ma'badong process try to reveal their ability by bring a producer and culture maker. They also have a role as a social institution such as school and family that is besides able to entertaining also able to do other positive functions such as production, socialization, teaching values, education, giving information, or become a social control toward the children, teenagers, workers, ethnical groups, or other groups in a society. It can be concluded that Ma'badong is a cultural product that can be a heritage media of Toraja.

\section{Closing}

Analyzing both of Simon and Luther's statement, it could be said that the inheritance media show in the Toraja's society was a statically factual record. It meant as Toraja's people, Ma'badong inheritance media show which was experienced since being child until being adult was being a routine activity which had no many changing (statically) as the custom rule which applied by Toraja's society. Such as head movement, shoulder, hand, and foot, also the rotation, there were no change and variation, likewise the arrangement which was still exist since the past until now. Even though there was a social change in the society generally, but the Toraja's society as a community, should face it then kept the principle on the custom rule which was followed and complied hereditary by Toraja's people.

The delineation of Toraja's society condition as described above was in line with Edi Sediyawati view (in Arif Budi Wurianto, 2005, p. 215) who stated that a society who was aware and able to respect their inheritance custom mostly able to adapt harmonically toward modernization dynamism. Cases which were understood as Walat (rebellious) such as cases which based on the outsider's view were deemed to be a myth, were precisely deemed to be a custom strength for the native society and could be utilized as a filtering or screening toward the influence of the other custom.

Ma'badong as a religious inheritance media show which engaged a strong and sturdy emotional enchantment by the followers, had an impact toward the Toraja's believe as a feed back of the belief system which was dominated by an ideal image which at last formed Toraja's people character or inter human relationship, especially as a fellow Aluk Todolok believer, also toward the supernatural cases due to their belief. Indeed, sometimes religion aspect was exceedingly centralized the attention toward the indication which was deemed to be an exceptionally and irrational thing, however it had very important role in guiding the believer society. Therefore in Toraja, a religion activity was done as a belief realization which was a daily life reflection. The purpose was to reduce the anxiety (afraid, horrifies, and other similar feeling).

For Toraja's people, the result of anxiety feeling created a fully self surrender toward 'something' which occupied a central position in Aluk Todolok belief which was followed without being rationalized beforehand. As a custom phenomenon, a religious message which was stated through the inheritance media as an example it could not be separated with the cultural context generally. If there was an agreement reached that belief was a part of culture (particularly a belief that was developed by certain society), at least it was begun from the process until arrived in the believer society, it could not be apart from the symbols utilizing which was believed that contained a holy and sacred value.

In the social reality, there were many society groups or society members as individual who was guided by the religious rules, or belief which was developed by certain society groups that was followed and believed. In order to do the activity related to their followed religion rule implementation and practical, commonly the society held 
a ceremony where one of the equipment was done by the inheritance media show. The delivering message was called by religious message due to the relationship among human and God, inter human, and among human and the surroundings. According to Yusuf Akib (2003: 13), this case happened because a developed religion or belief by a certain society could be meant as a set of rule and regulation which regulated the relationship among human and God, inter human, and regulated the relationship among human and the environment.

Therefore, the social ritual activity of Toraja's funeral, beside paid an attention to the custom symbols, wearing clothes and accessories also got a special attention because all of it would show the society members' position and social status. It was similar with Barnard (1996: 97) statement that in attending wedding or funeral ceremony, people was not allowed to wear daily clothes, while people tended to wear newer and better cloths because except it was determined by a ritual regulation, it also would show someone's social status.

\section{References}

Abidin, A. Z. (1999). Capita Selekta Kebudayaan Sulawesi Selatan. Ujung Pandang: Hasanuddin University Press.

Adhikarya, R., \& Crawford, R. (1979). The Use of Tradisional Media in Family Planning in Rural Java. Ithaca.

Afrisal et al. (2007). Media Rakyat; Mengorganisasi Diri Melalui Informasi. Jogjakarta: Combine Resource Institution Bekerja sama dengan The Ford Foundation.

Bakar, A. L. A., \& Imran, M. N. (1999). Media Warisan Malaysia. Kuala Lumpur: Jabatan Pengajian Media Universiti Malaya.

Burton, G. (2008). Pengantar untuk Memahami Media Dan Budaya Populer. Jogjakarta: Jalasutra.

Dananjaya, J. (1972). Bagaimana Memanfaatkan Media Tradisional Bagi Pembangunan Desa. Jakrta: Grafiti.

Dananjaya, J. (1994). Folklor Indonesia: Ilmu Gosip, Dongeng dan Lain-lain. Jakarta: Grafiti.

Dasen, P. R., \& Mishra, dan R. C. (2000). Cross-Cultural Views on Human Development in the Third Millennium. Internasional Journal of Behavioral Development, 24(4), 428-434. http://dx.doi.org/10.1080/016502500750037973

Dashefsky, A. (Ed.). (1976). Ethnic identity in Society. Chicago: Rand Memelly College.

Departemen Komunikasi dan Informatika Republik Indonesia. (2007). Kerangka Acuan Arah Pengembangan dan Pemberdayaan Lembaga Media tradisional. Jakarta. Direktorat Kelembagaan Komunikasi Sosial Ditjen. Sarana Komunikasi dan Diseminasi Informasi.

Foley, J. M. (1981). Oral Traditional Literature. Colombus Ohio: Slavica Publishers Inc.

Hamid, A. (2007). Pesan-Pesan Moral Pelaut Bugis. Makassar: Pustaka Refleksi.

Hamidy. (1975). Randai Sebagai Saluran Media Komunikasi Tradisional. Makalah Seminar. Yogyakarta: LP3ES.

Hamzuri, \& Siregar, T. R. (1998). Permainan Tradisional Indonesia. Proyek Jakarta: Pembinaan Permeseuman Direktorarat Jenderal Kebudayaan Departemen Pendidikan Dan Kebudayaan.

Hardwick, C. (1973). Traditions, Superstitions, and Folk-lore. England: The Scolar Press Limited Menston.

Hedebro, G. (1993). Komunikasi dan Perubahan Sosial (Dalam Jurnal Komunikasi “Audientia”). Kerjasama LP3K, SPS, Humas Pemda Jawa Barat, ISKI Cabang Bandung, dan PT. Rosdakarya.

Hidayah, Z. (1997). Ensiklopedi Suku Bangsa di Indonesia. Jakarta: LP3ES.

Hidayat, K. (1996). Memahami Bahasa Agama: Sebuah Kajian Hermeneutik. Jakarta: Paramadina.

Ishomuddin. (2007). Agama Produsen Realitas; Tafsir Islam-Tradisi Masyarakat Model Prismatik. Malang: UMM Press.

Jahi, A. (1988). Komunikasi Massa dan Pembangunan Pedesaan di Negara-Negara Dunia Ketiga. Jakarta: PT Gramedia.

Jayaweera, N., \& Amunugama, S. (1995). Mengkaji Semula Komunikasi Pembangunan. Kuala Lumpur: Dewan Bahasa dan Pustaka.

Joko. (1975). Pemimpin Agama dan Media Komunikasi Tradisional di Pedesaan. Jogjakarta: Makalah Seminar. LP3ES. 
Kumaria, A. (1980). Communication and Tradisional Media. Proceedings of a seminar hald at Prune. Dalam Communicator, 15(3), 12-17.

Leckenby, J. D., \& Collier, E. D. (2003). The Interaction of Traditional and New Media. Texas: Departement of Advertising College of Communication, The University of Texas at Austin.

Living Tradisions. (1995). Manila: Asean Committee on Culture and Information.

Mattulada et al. (1977). Geografi Budaya Daerah Sulawesi Selatan. Jakarta: Proyek Penelitian dan Pencatatan Kebudayaan Daerah Departemen Pendidikan Dan Kebudayaan.

McQuail, D. (1989). Teori komunikasi Massa. Jakarta. Erlangga.

Mieder, W. (1987). Tradition And Innovation In Folk Literature. Honover: University Press of New England.

Monoharto, G., \& Kawan-kawan. (2003). Seni Tradisional Sulawesi Selatan. Makassar: Lamacca Press.

Muhtamar, S. (2007). Masa Depan Warisan Luhur Kebudayaan Sulsel. Makassar: Pustaka Refleksi.

Mulyana, D. (2007). Ilmu Komunikasi Suatu Pengantar. Bandung: Remadja Rosdakarya.

Nurudin. (2004). Sistem Komunikasi Indonesia. Jakarta: PT Raja Grafindo Persada.

Oepen, M. (1988). Media Rakyat: Komunikasi Pengembangan masyarakat. Jakarta: P3M.

Orewere, B. (1991). Posible Implications of Modern Mass Media for Tradisional Communication in a Nigerian Rural Setting. Africa Media Review, 5(3). Nigeria: African Council for Communication Education.

Paeni, M., \& Pudentia. (2005). Bunga Rampai Budaya Berpikir Positif Suku-Suku Bangsa. Jakarta: Departemen Kebudayaan dan Pariwisata bekerjasama Dengan Asosiasi Tradisi Lisan (ATL).

Permaianan Rakyat Sulawesi Selatan. (2003). Makassar: Lamacca Press.

Rahman, N. (2005). Katalog Tradisi Lisan Komunitas Adat Terpencil Sulawesi Selatan. Makassar: Lagaligo Press.

Sitonda, M. N. (2007). Toraja Warisan Dunia. Makassar: Pustaka Refleksi.

Stokes, J. (2007). How To Do Media and Cultural Studies Panduan Untuk Melaksanakan Kajian dalam Kajian Media dan Budaya. Penterjemah Santi Indra Astuti. Jogjakarta: Bentang Pustaka.

Sutherland, H. et al. (2004). Kontinuitas \& Perubahan Dalam Sejarah Sulawesi Selatan. Disunting Oleh Dias Pradadimara \& Muslimin A. R. Effendy. Jogjakarta: Ombak.

Syekh Yusuf Makassar; Seorang Ulama, Sufi dan Pejuang. (1994). Jakarta: Yayasan Obor Indonesia.

Tiongsong, N. G. (1986). The Cultural Traditional Media of Asean. Manila: Asean committee on Culture and Information.

Toffler, A. (1992). Kejutan Masa Depan. Jakarta: PT. Pantja Simpati.

Vansina, J. (1972). Oral Tradition; A Study in Historical Methodology. London: Routledge \& Kegan Paul.

Wach, J., \& Joseph, M. (1960). The Comparative Study of Religions. Review by: Seymour Cain. The Journal of Religion, 40(1), 47-49. Published by: The University of Chicago Press.

Wahid, S. (2007). Manusia Makassar. Makassar: Pustaka Refleksi.

Wurianto, A. B. (2005). Seni Pertunjukan Masyarakat Tengger: Sebuah Identitas, Kontinuitas, dan Perubahannya dalam Perspektif Budaya. Bali: Disertasi Pada Program Pascasarjana Universitas Udayana Denpasar.

\section{Notes}

Note 1. Ma'badong was formed from two words they were ' $M a$ ' which meant as doing and 'badong' was a dancing name so that Ma'badong meant as doing badong dance and song. While the player was called as Pa'badong (word ' $\mathrm{Pa}$ ' meant as player, so Pa'badong was persons who play badong dance and song.

Note 2. Lantang was a custom building which was only made for once using at the moment of last offices. This custom building was made from wood and board which would be took apart after the lst offices.

Note 3. Ma'badong activity was only held when the corpse was not burried yet or still in the grief home, and Ma'badong activity was not allowed if the dead person was burried. Toraja's people commomly would not directly be burried but waited for the family agreement, sometimes the funeral was done after days, weeks, 
months, even years measurement.

Note 4. Aluk meant religion, Todolok meant forefathers. Aluk Todolok meant as the forefathers' religion.

Note 5. Rambu Solok was a ceremony due to a death and position where consisted of religion and social dymension for Toraja's people.

Note 6. Spirit's world, heaven, or the beyond.

Note 7. Tedong Bonga was a stripe water buffalo which was deemed only lived in Toraja, it had a beautiful horns, posture, body color, and eyes.

Note 8. Many responses and comments turned up due to the last offices in Toraja, some people said that ceremony only a great wasting, because in that ceremony it was just wasting much money, but there was other opinion that a custom ceremony could not be measured by money, because this case related to human's feeling.

Note 9. Tongkonan was a name of Toraja's custom building with the characteristic of wooden stage house where the space underneath of the house was used as water buffaloes stall. The roof was layered by black palm fiber and the arched shape that was similiar with a downward ship consisted of astern. But there were people who had a hunch that the shape looked like water buffalo's horn.

\section{Copyrights}

Copyright for this article is retained by the author(s), with first publication rights granted to the journal.

This is an open-access article distributed under the terms and conditions of the Creative Commons Attribution license (http://creativecommons.org/licenses/by/3.0/). 